\title{
THE ORIGINS OF ATTACHMENT THEORY: JOHN BOWLBY AND MARY AINSWORTH INGE BRETHERTON
}

Attachment theory is the joint work of John Bowlby and Mary Ainsworth (Ainsworth \& Bowlby, 1991 ). Drawing on concepts from ethology, cybernetics, information processing, developmental psychology, and psychoanalysts, John Bowlby formulated the basic tenets of the theory. He thereby revolutionized our thinking about a child's tie to the mother and its disruption through separation, deprivation, and bereavement. Mary Ainsworth's innovative methodology not only made it possible to test some of Bowlby's ideas empirically hut also helped expand the theory itself and is responsible for some of the new directions it is now taking. Ainsworth contributed the concept of the attachment figure as a secure base from which an infant can explore the world. In addition, she formulated the concept of maternal sensitivity to infant signals and its role in the development of infant-mother attachment patterns.

The ideas now guiding attachment theory have a long developmental history. Although Bowlby and Ainsworth worked independently of each other during their early careers, both were influenced by Freud and other psychoanalytic thinkers-directly in Bowlby's case, indirectly in Ainsworth's. In this chapter, I document the origins of ideas that later became central to attachment theory. I then discuss the subsequent period of theory building and consolidation. Finally, I review some of the new directions in which the theory is currently developing and speculate on its future potential In taking this retrospective developmental approach to the origins of attachment theory, I am reminded of Freud's (1920/1955) remark:

I would like to thank Mary Ainsworth and Ursula Bowlby for helpful input on a draft of this article. I am also grateful for insightful comments by three very knowledgeable reviewers.

Reference: Developmental Psychology (1992), 28, 759-775. Reprinted in from R. Parke, P. Ornstein, J. Reiser, \& C. Zahn-Waxler (Eds.) (1994). A century of developmental psychology. (Chapter 15, pp. 431-471). 
So long as we trace the development from its final outcome backwards, the chain of events appears continuous, and we feel we have gained an insight which is completely satisfactory or even exhaustive. But if we proceed in the reverse way, if we start from the premises inferred from the analysis and try to follow these up to the final results, then we no longer get the impression of an inevitable sequence of events which could not have otherwise been determined. (p. 167)

In elucidating how each idea and methodological advance became a stepping stone for the next, my retrospective account of the origins of attachment theory makes the process of theory building seem planful and orderly. No doubt this was the case to some extent, but it may often not have seemed so to the protagonists at the time.

\section{ORIGINS}

\section{John Bowlby}

After graduating from the University of Cambridge in 1928, where he received rigorous scientific training and some instruction in what is now called developmental psychology, Bowlby performed volunteer work at a school for maladjusted children while reconsidering his career goals. His experiences with two children at the school set his professional life on course. One was a very isolated, remote, affectionless teenager who had been expelled from his previous school for theft and had had no stable mother figure. The second child was an anxious boy of 7 or 8 who trailed Bowlby around and who was known as his shadow (Ainsworth, 1974). Persuaded by this experience of the effects of early family relationships on personality development, Bowlby decided to embark on a career as a child psychiatrist (Senn, 1977h).

Concurrently with his studies in medicine and psychiatry, Bowlby undertook training at the British Psychoanalytic Institute. During this period Melanie Klein was a major influence there (the institute had three groups: Group A sided with Freud, Group B sided with Klein, and the Middle Group sided with neither). Bowlby was exposed to Kleinian (Klein, 1932) ideas through his training analyst, Joan Riviere, a close associate of Klein, and eventually through supervision by Melanie Klein herself. Although he acknowledges Riviere and Klein for grounding him in the 
object-relations approach to psychoanalysis, with its emphasis on early relationships and the pathogenic potential of loss (Bowlby, 1969, p. xvii), he had grave reservations about aspects of the Kleinian approach to child psychoanalysis. Klein held that children's emotional problems are almost entirely due to fantasies generated from internal conflict between aggressive and libidinal drives, rather than to events in the external world, She hence forbade Bowlby to talk to the mother of a 3-year-old whom he analyzed under her supervision (Bowlby, 1987). This was anathema to Bowlby who, in the course of his postgraduate training with two psychoanalytically trained social workers at the London Child Guidance Clinic, had come to believe that actual family experiences were a much more important, if not the basic, cause of emotional disturbance.

Bowlby's plan to counter Klein's ideas through research is manifest in an early theoretical paper (1940) in which he proposed that, like nurserymen, psychoanalysts should study the nature of the organism, the properties of the soil, and their interaction (p. 23). He goes on to suggest that, for mothers with parenting difficulties,

a weekly interview in which their problems are approached analytically and traced hack to childhood has sometimes been remarkably effective. Having once been helped to recognize and recapture the feelings which she herself had as a child and to find that they are accepted tolerantly and understandingly, a mother will become increasingly sympathetic and tolerant toward the same things in her child. (Bowlby, 1940, p. 23)

These quotations reveal Bowlby's early theoretical and clinical interest in the intergenerational transmission of attachment relations and in the possibility of helping children by helping parents. Psychoanalytic object-relations theories later proposed by Fairbain (1952) and Winnicott (1965) were congenial to Bowlby, hut his thinking had developed independently of them.

Bowlby's first empirical study, based on case notes from the London Child Guidance Clinic, dates from this period. Like the boy at the school for maladjusted children, many of the clinic patients were affectionless and prone to stealing. Through detailed examination of 44 cases, Bowlby was able to link their symptoms to histories of maternal deprivation and separation.

Although World War II led to an interruption in Bowlby's budding career as a practicing child psychiatrist, it laid further groundwork for his career as a researcher. His assignment was to collaborate on officer selection procedures with a group of distinguished colleagues from the Tavistock Clinic in London, an experience that gave Bowlby a level of methodological and 
statistical expertise then unusual for a psychiatrist and psychoanalyst. This training is obvious in the revision of his paper, "Forty-Four Juvenile Thieves: Their Characters and Home Lives" (Bowlby, 1944), which includes statistical tests as well as detailed case histories.

At the end of World War II, Bowlby was invited to become head of the Children's Department at the Tavistock Clinic. In line with his earlier ideas on the importance of family relationships in child therapy, he promptly renamed it the Department for Children and Parents. Indeed, in what is credited as the first published paper in family therapy, Bowlby (1949) describes how he was often able to achieve clinical breakthroughs by interviewing parents about their childhood experiences in the presence of their troubled children.

To Bowlby's chagrin, however, much of the clinical work in the department was done by people with a Kleinian orientation, who, he says, regarded his emphasis on actual family interaction patterns as not particularly relevant. He therefore decided to found his own research unit whose efforts were focused on mother-child separation. Because separation is a clear-cut and undeniable event, its effects on the child and the parent- child relationship were easier to document than more subtle influences of parental and familial interaction.

\section{Mary Ainsworth}

Mary Ainsworth (nee Salter), 6 years younger than Bowlby, finished graduate study at the University of Toronto just before World War II. courses with William Blatz had introduced her to security theory (Blatz, 1940), which both reformulated and challenged Freudian ideas, though Blatz chose not to recognize his debt to Freud because of the anti-Freudian climate that pervaded the University of Toronto at that time (Ainsworth, 1983; Blatz, 1966).

One of the major tenets of security theory is that infants and young children need to develop a secure dependence on parents before launching out into unfamiliar situations. In her dissertation, entitled "An Evaluation of Adjustment Based Upon the Concept of Security," Mary Salter (1940) states it this way:

Familial security in the early stages is of a dependent type and forms a basis from which the individual can work out gradually, forming new skills and interests in other fields. Where familial security is lacking, the individual is handicapped by the lack o what might be called a secure base italics added from which to work. (p. 45) 
Interestingly, Mary Salter's dissertation research included an analysis of students' autobiographical narratives in support of the validity of her paper-and-pencil self-report scales of familial and extrafamilial security, foreshadowing her later penchant for narrative methods of data collection. Indeed, few researchers realize the enormous experience in instrument development and diagnostics she brought to attachment research.

Like Bowlby's, Mary Salter's professional career was shaped by her duties as a military officer during World War 11 (in the Canadian Women's Army corps). After the war, as a faculty member at the University of Toronto, she set out to deepen her clinical skills in response to the request to teach courses in personality assessment. To prepare herself for this task, she signed up for workshops by Bruno Klopfer, a noted expert in the interpretation of the Rorschach test. This experience led to a coauthored book on the Rorschach technique (Klopfer, Ainsworth, Klopfer, $\&$ Holt, 1954), which is still in print.

In 1950, Mary Salter married Leonard Ainsworth and accompanied him to London, where he completed his doctoral studies. Someone there drew her attention to a job advertisement in the London Times that happened to involve research, under the direction of John Bowlby, into the effect on personality development of separation from the mother in early childhood. As Mary Ainsworth acknowledges, joining Bowlby's research unit reset the whole direction of her professional career, though neither Bowlby nor Ainsworth realized this at the time.

\section{THE EMERGENCE OF ATTACHMENT THEORY}

In 1948, 2 years before Ainsworth's arrival, Bowlby had hired James Robertson to help him observe hospitalized and institutionalized children who were separated from their parents. Robertson had had impeccable training in naturalistic observation, obtained as a conscientious objector during World War II, when he was employed as a boilerman in Anna Freud's Hampstead residential nursery for homeless children. Anna Freud required that all members of the staff, no matter what their training or background, write notes on cards about the children's behavior (Senn, 1977a), which were then used as a basis for weekly group discussions. The thorough training in child observation that Robertson thus obtained at the Hampstead residential nursery is Anna Freud's lasting personal contribution to the development of attachment theory.

After 2 years of collecting data on hospitalized children for Bowlby's research projects, 
Robertson protested that he could not continue as an uninvolved research worker, but felt compelled to do something for the children he had been observing. On a shoestring budget, with minimal training, a hand-held cinecamera, and no artificial lighting, he made the deeply moving film, A Two-Year-Old Goes to Hospital (Robertson, 1 953a, 1953b; Robertson \& Bowlby, 1952). Foreseeing the potential impact of this film, Bowlby insisted that it be carefully planned to ensure that no one would later he able to accuse Robertson of biased recording. The target child was randomly selected, and the hospital clock on the wall served as proof that time sampling took place at regular periods of the day. Together with Spitz's (1947) film, Grief: A Peril in Infancy, Robertson's first film helped improve the fate of hospitalized children all over the Western world, even though it was initially highly controversial among the medical establishment.

When Mary Ainsworth arrived at Bowlby's research unit late in 1950, others working there (besides James Robertson) were Mary Boston and Dina Rosenbluth. Rudolph Schaffer, whose subsequent attachment research is well known (Schaffer \& Emerson, 1964), joined the group somewhat later, as did Christoph Heinicke (1956; Heinicke \& Westheimer, 1966), who undertook additional separation and reunion studies, and Tony Ambrose (1961), who was interested in early social behavior. Mary Ainsworth, who was charged with analyzing James Robertson's data, was tremendously impressed with his records of children's behavior and decided that she would emulate his methods of naturalistic observation were she ever to undertake a study of her own (Ainsworth, 1983).

At this time, Bowlby's earlier writings about the familial experiences of affectionless children had led Ronald Hargreaves of the World Health Organization (WHO) to commission him to write a report on the mental health of homeless children in postwar Europe. Preparation of the WHO report gave Bowlby an opportunity to pick the brains of many practitioners and researchers across Europe and the United States who were concerned with the effects of maternal separation and deprivation on young children, including Spitz (1946) and Goldfarb (1943, 1945). The report was written in 6 months and translated into 14 languages, with sales of 400,000 copies in the English paperback edition; it was published in 1951 as Maternal Care and Mental Health by the WHO. A second edition, entitled Child Care and the Growth of Love, with review chapters by Mary Ainsworth, was published by Penguin Books in 1965. 
It is interesting to examine the 1951 report from today's perspective. At that time Bowlby still used the terminology of traditional psychoanalysis (love object, libidinal ties, ego, and superego), hut his ideas were little short of heretical, Perhaps following Spitz, he used embryology as a metaphor to portray the maternal role in child development:

If growth is to proceed smoothly, the tissues must he exposed to the influence of the appropriate organizer at certain critical periods. In the same way, f mental development is to proceed smoothly, it would appear to he necessary for the undifferentiated psyche to be exposed during certain critical periods to the influence of the psychic organizer- the mother. (Bowlby, 1951, p. 53)

Then, seemingly doing away with the idea that the superego has its origin in the resolution of the Oedipus complex, Bowlby claims that during the early years, while the child acquires the capacity for self-regulation, the mother is a child's ego and superego:

It is not surprising that during infancy and early childhood these functions are either not operating at all or are doing so most imperfectly. During this phase of life, the child is therefore dependent on his mother performing them for him. She orients him in space and time, provides his environment, permits the satisfaction of some impulses, restricts others. She is his ego and his super-ego. Gradually he learns these arts himself, and as he does, the skilled parent transfers the roles to him. This is a slow, subtle and continuous process, beginning when he first learns to walk and feed himself, and not ending completely until maturity is reached.... Ego and super-ego development are thus inextricably hound up with the child's primary human relationships. (Bowlby, 1951, p. 53)

This sounds more Vygotskian than Freudian. Moreover, despite his disagreements with Kleinian therapy, I detect remnants of Kleinian ideas in Bowlby's discussions of children's violent fantasies on returning to parents after a prolonged separation and "the intense depression that humans experience as a result of hating the person they most dearly love and need" (Bowlby, 1951, p. $57)$.

Bowlby's major conclusion, grounded in the available empirical evidence, was that to grow up mentally healthy, "the infant and young child should experience a warm, intimate, and continuous relationship with his mother (or permanent mother substitute) in which both find satisfaction and enjoyment" (Bowlby, 1951, p. 13). Later summaries often overlook the reference to the substitute mother and to the partners' mutual enjoyment. They also neglect Bowlby's emphasis on the role of social networks and on economic as well as health factors in the development of well-functioning mother-child relationships. His call to society to provide support 
for parents is still not heeded today:

Just as children are absolutely dependent on their parents for sustenance, so in all hut the most primitive communities, are parents, especially their mothers, dependent on a greater society for economic provision. If a community values its children it must cherish their parents. (Bowlby, 1951, p. 84)

True to the era in which the WHO report was written, Bowlby emphasized the female parent. In infancy, he comments, fathers have their uses, but normally play second fiddle to mother. Their prime role is to provide emotional support to their wives' mothering.

The proposition that, to thrive emotionally, children need a close and continuous caregiving relationship called for a theoretical explanation. Bowlby was not satisfied with the then current psychoanalytic view that love of mother derives from sensuous oral gratification, nor did he agree with social learning theory's claim that dependency is based on secondary reinforcement (a concept that was itself derived from psychoanalytic ideas). Like Spitz (1946) and Erikson (1950), Bowlby had latched onto the concept of critical periods in embryological development and was casting about for similar phenomena at the behavioral level when, through a friend, he happened upon an English translation of Konrad Lorenz's (1935) paper on imprinting.

From then on, Bowlby began to mine ethology for useful new concepts. Lorenz's (1935) account of imprinting in geese and other precocial birds especially intrigued him, because it suggested that social bond formation need not be tied to feeding. In addition, he favored ethological methods of observing animals in their natural environment, because this approach was so compatible with the methods Robertson had already developed at the Tavistock research unit.

One notable talent that stood Bowlby in great stead throughout his professional life was his ability to draw to himself outstanding individuals who were willing and able to help him acquire expertise in new fields of inquiry that he needed to master in the service of theory building To learn more about ethology, Bowlby contacted Robert Hinde, under whose "generous and stern guidance" (see Bowlby, 1980b, p. 650) he mastered ethological principles to help him find new ways of thinking about infant mother attachment. Conversely, Hinde's fascinating studies of individual differences in separation and reunion behaviors of group-living rhesus mother infant dyads (Hinde \& Spencer-Booth, 1967) were inspired by the contact with Bowlby and his co-workers (Hinde, 1991). 
Bowlby's first ethological paper appeared in 1953. Somewhat surprisingly, however, various empirical papers on the effects of separation, published with his own research team during the very same period, show little trace of Bowlby's new thinking, because his colleagues were unconvinced that ethology was relevant to the mother-child relationship (Bowlby, personal communication, October 1986). Even Mary Ainsworth, though much enamored of ethology, was somewhat wary of the direction Bowlby's theorizing had begun to take. It was obvious to her, she said, that a baby loves his mother because she satisfies his needs (Ainsworth, personal communication, January 1992), A collaborative paper dating from this period (Bowlby, Ainsworth, Boston, \& Rosenbluth, 1956) is nevertheless important, because it prefigures later work on patterns of attachment by Ainsworth. Her contribution to the paper was a system for classifying three basic relationship patterns in school-age children who had been reunited with parents after prolonged sanatorium stays: those with strong positive feelings toward their mothers; those with markedly ambivalent relationships; and a third group with nonexpressive, indifferent, or hostile relationships with mother.

\section{THE FORMULATION OF ATTACHMENT THEORY AND THE FIRST ATTACHMENT STUDY}

\section{Theoretical Formulations}

Bowlby's first formal statement of attachment theory, building on concepts from ethology and developmental psychology, was presented to the British Psychoanalytic Society in London in three now classic papers: "The Nature of the Child's Tie to His Mother" (1958), "Separation Anxiety" (1959), and "Grief and Mourning in Infancy and Early Childhood" (1960). By 1962 Bowlby had completed two further papers (never published; $1962 \mathrm{a}$ and b) on defensive processes related to mourning. These five papers represent the first basic blueprint of attachment theory.

\section{The Nature of the Child's Tie to His Mother}

This paper reviews and then rejects those contemporary psychoanalytic explanations for the child's libidinal tie to the mother in which need satisfaction is seen as primary and attachment as secondary or derived. Borrowing from Freud's (1905/1953) notion that mature human sexuality is built up of component instincts, Bowlby proposed that I 2-month-olds' unmistakable attach- 
ment behavior is made up of a number of component instinctual responses that have the function of binding the infant to the mother and the mother to the infant. These component responses (among them sucking, clinging, and following, as well as the signaling behaviors of smiling and crying) mature relatively independently during the first year of life and become increasingly integrated and focused on a mother figure during the second 6 months. Bowlby saw clinging and following as possibly more important for attachment than sucking and crying.

To buttress his arguments, Bowlby reviewed data from existing empirical studies of infants' cognitive and social development, including those of Piaget $(1951,1954)$, with whose ideas he had become acquainted during a series of meetings by the "Psychobiology of the Child" study group, organized by the same Ronald I Hargreaves at the World Health Organization who had commissioned Bowlby's 1951 report. These informative meetings, also attended by Erik Erikson, Julian Huxley, Baerbel Inhelder, Konrad Lorenz, Margaret Mead, and Ludwig von Bertalanffy, took place between 1953 and 1956. (Proceedings were published by Tavistock Publications.) For additional evidence, Bowlby drew on many years of experience as weekly facilitator of a support group for young mothers in London.

After his careful discussion of infant development, Bowlby introduced ethological concepts, such as sign stimuli or social releasers that "cause" specific responses to he activated and shut off or terminated (see Tinbergen, 1951). These stimuli could he external or intrapsychic, an important point in view of the fact that some psychoanalysts accused Bowlby of behaviorism because he supposedly ignored mental phenomena. Bowlby also took great pains to draw a clear distinction between the old social learning theory concept of dependency and the new concept of attachment, noting that attachment is not indicative of regression, hut rather performs a natural, healthy function even in adult life.

Bowlby's new instinct theory raised quite a storm at the British Psychoanalytic Society. Even Bowlby's own analyst, Joan Riviere, protested. Anna Freud, who missed the meeting but read the paper, politely wrote:

"Dr. Bowlby is too valuable a person to get lost to psychoanalysis" (Grosskurth, 1987).

\section{Separation Anxiety}


The second seminal paper (Bowlby, 1959) builds on observations by Robertson (1953b) and Heinicke (1956; later elaborated as Heinicke \& Westheimer, 1966), as well as on Harlow and Zimmermann's (1958) groundbreaking work on the effects of maternal deprivation in rhesus monkeys. Traditional theory, Bowlby claims, can explain neither the intense attachment of infants and young children to a mother figure nor their dramatic responses to separation.

Robertson (Robertson \& Bowlby, 1952) had identified three phases of separation response: protest (related to separation anxiety), despair (related to grief and mourning), and denial or detachment (related to defence mechanisms, especially repression). Again drawing on ethological concepts regarding the control of behavior, Bowlby maintained that infants and children experience separation anxiety when a situation activates both escape and attachment behavior hut an attachment figure is not available.

The following quote explains, in part, why some psychoanalytic colleagues called Bowlby a behaviorist: "for to have a deep attachment for a person (or a place or thing) is to have taken them as the terminating object of our instinctual responses" (Bowlby, 1959, p. 13). The oddity of this statement derives from mixing, in the same sentence, experiential language (to have a deep attachment) with explanatory language representing an external observer's point of view (the attachment figure as the terminating object).

In this paper, Bowlby also took issue with Freud's claim that maternal overgratification is a danger in infancy. Freud failed to realize, says Bowlby, that maternal pseudo-affection and overprotection may derive from a mother's overcompensation for unconscious hostility. In Bowlby's view, excessive separation anxiety is due to adverse family experiences-such as repeated threats of abandonment or rejection by parents-or to a parent's or sibling's illness or death for which the child feels responsible.

Bowlby also pointed out that, in some cases, separation anxiety can be excessively low or be altogether absent, giving an erroneous impression of maturity. He attributes pseudoindependence under these conditions to defensive processes. A well-loved child, he claims, is quite likely to protest separation from parents but will later develop more self-reliance, These ideas reemerged later in Ainsworth's classifications of ambivalent, avoidant, and secure patterns of infant-mother attachment (Ainsworth, Blehar, Waters, \& Wall, 1978). 


\section{Grief and Mourning in Infancy and Early Childhood}

In the third, most controversial paper, Bowlby (1960) questioned Anna Freud's contention that bereaved infants cannot mourn because of insufficient ego development and therefore experience nothing more than brief bouts of separation anxiety if an adequate substitute caregiver is available. In contrast, Bowlby (citing Marris, 1958) claimed that grief and mourning processes in children and adults appear whenever attachment behaviors are activated but the attachment figure continues to he unavailable. He also suggested that an inability to form deep relationships with others may result when the succession of substitutes is too frequent.

As with the first paper, this paper also drew strong objections from many members of the British Psychoanalytic Society. One analyst is said to have exclaimed: "Bowlby? Give me Barrabas" (Grosskurth, 1987). Controversy also accompanied the published version of this paper in The Psychoanalytic Study of the Child. Unbeknownst to Bowlby, rejoinders had been invited from Anna Freud (1960), Max Schur (1960), and René Spitz (1960), all of whom protested various aspects of Bowlby's revision of Freudian theory. Spitz ended his rejoinder by saying:

When submitting new theories we should not violate the principle of parsimony in science by offering hypotheses which in contrast to existing theory becloud the observational facts, are oversimplified, and make no contribution to the better understanding of observed phenomena. (p. 93)

Despite this concerted attack, Bowlby remained a member of the British Psychoanalytic Society for the rest of his life, although he never again used it as a forum for discussing his ideas. At a meeting of the society in memory of John Bowlby, Eric Rayner (1991) expressed his regret at this turn of events:

What seems wrong is when a theorist extols his own view by rubbishing others; Bowlby received this treatment. ... Our therapeutic frame of mind is altered by theory. John Bowlby was a great alterer of frames of mind.

Bowlby's controversial paper on mourning attracted the attention of Colin Parkes, now well known for his research on adult bereavement. Parkes saw the relevance of Bowlby's and Robertson's work on mourning in infancy and childhood for gaining insight into the process of adult grief. On joining Bowlby's research unit at the Tavistock Institute in 1962, Parkes set out to study a nonclinical group of widows in their homes to chart the course of nominal adult grief, about which little was known at the time, The findings led to a joint paper with Bowlby (Bowlby 
\& Parkes, 1970) in which the phases of separation response delineated by Robertson for young children were elaborated into four phases of grief during adult life: (a) numbness, (h) yearning and protest, (c) disorganization and despair, and (d) reorganization (see also Parkes, 1972).

Before the publication of the 1970 paper, Parkes had visited Elizabeth Kubler-Ross in Chicago, who was then gathering data for her influential book On Death and Dying (1978). The phases of dying described in her book (denial, anger, bargaining, depression, and acceptance) owe much to Bowlby's and Robertson's thinking. Bowlby also introduced Parkes to the founder of the modern hospice movement, Cicely Saunders. Saunders and Parkes used attachment theory and research in developing programs for the emotional care of the dying and bereaved, What they found particularly helpful in countering negative attitudes to the dying and bereaved was the concept of grief as a process toward attaining a new identity, rather than as a state (Parkes, personal communication, November 1989).

\section{The First Empirical Study of Attachment: Infancy in Uganda}

Let us now return to Mary Ainsworth's work. In late 1953, she had left the Tavistock Clinic, obviously quite familiar with Bowlby's thinking about ethology hut not convinced of its value for understanding infant- mother attachment. The Ainsworths were headed for Uganda, where Leonard Ainsworth had obtained a position at the East African Institute of Social Research at Kampala. With help from the same institute, Mary Ainsworth was able to scrape together funds for an observational study, but not before writing Bowlby a letter in which she called for empirical validation of his ethological notions (Ainsworth, January 1992, personal communication),

Inspired by her analyses of Robertson's data, Ainsworth had initially planned an investigation of toddlers' separation responses during weaning, but it soon became obvious that the old tradition of sending the child away "to forget the breast" had broken down. She therefore decided to switch gears and observe the development of infant-mother attachment.

As soon as she began her data collection, Ainsworth was struck by the pertinence of Bowlby's ideas, Hence, the first study of infant-mother attachment from an ethological perspective was undertaken several years before the publication of the three seminal papers in which Bowlby $(1958,1959,1960)$ laid out attachment theory. 
Ainsworth recruited 26 families with unweaned babies (ages 1 - 24 months) whom she observed every 2 weeks for 2 hours per visit over a period of up to 9 months. Visits (with an interpreter) took place in the family living room, where Ganda women generally entertain in the afternoon. Ainsworth was particularly interested in determining the onset of proximity-promoting signals and behaviors, noting carefully when these signals and behaviors became preferentially directed toward the mother.

On leaving Uganda in 1955, the Ainsworths moved to Baltimore, where Mary Ainsworth began work as a diagnostician and part-time clinician at the Sheppard and Enoch Pratt Hospital, further consolidating her already considerable assessment skills. At the same time, she taught clinical and developmental courses at the Johns Hopkins University, where she was initially hired as a lecturer. Because of her involvement in diagnostic work and teaching, the data from the Ganda project lay fallow for several years.

\section{REFINING ATTACHMENT THEORY AND RESEARCH: BOWLBY AND AINSWORTH}

Before the publication of "The Nature of the Child's Tie to His Mother" in 1958, Mary Ainsworth received a preprint of the paper from John Bowlby. This event led Bowlby and Ainsworth to renew their close intellectual collaboration. Ainsworth's subsequent analysis of data from her Ganda project (Ainsworth 1963, 1967) influenced and was influenced by Bowlby's reformulation of attachment theory (published in 1969). In this sharing of ideas, Ainsworth's theoretical contribution to Bowlby's presentation of the ontogeny of human attachment cannot be overestimated.

\section{Findings From Ainsworth's Ganda Project}

The Ganda data (Ainsworth, 1963, 1967) were a rich source for the study of individual differences in the quality of mother - infant interaction, the topic that Bowlby had earlier left aside as too difficult to study. Of special note, in light of Ainsworth's future work, was an evaluation of maternal sensitivity to infant signals, derived from interview data. Mothers who were excellent informants and who provided much spontaneous detail were rated as highly sensitive, in contrast to other mothers who seemed imperceptive of the nuances of infant behavior. Three infant 
attachment patterns were observed: Securely attached infants cried little and seemed content to explore in the presence of mother; insecurely attached infants cried frequently, even when held by their mothers, and explored little; and not-yet attached infants manifested no differential behavior to the mother.

It turned out that secure attachment was significantly correlated with maternal sensitivity. Babies of sensitive mothers tended to be securely attached, whereas babies of less sensitive mothers were more likely to he classified as insecure. Mothers' enjoyment of breast-feeding also correlated with infant security. These findings foreshadow some of Ainsworth's later work, although the measures are not yet as sophisticated as those developed for subsequent studies.

Ainsworth presented her initial findings from the Ganda project at meetings of the Tavistock Study Group organized by Bowlby during the 1960s (Ainsworth, 1963). Participants invited to these influential gatherings included many now-eminent infant researchers of diverse theoretical backgrounds (in addition to Mary Ainsworth, there were Genevieve Appell, Miriam David, Jacob Gewirtz, Hanus Papousek, Heinz Prechtl, Harriet Rheingold, Henry Ricciuti, Louis Sander, and Peter Wolff), as well as renowned animal researchers such as Harry Harlow, Robert Hinde, Charles Kaufmann, Jay Rosenblatt, and Thelma Rowell Their lively discussions and ensuing studies contributed much to the developing field of infant social development in general. Importantly for Bowlby, they also enriched his ongoing elaboration of attachment theory. Bowlby had always believed that he had much to gain from bringing together researchers with different theoretical backgrounds (e.g., learning theory, psychoanalysis, and ethology), whether or not thy agreed with his theoretical position. Proceedings of these fruitful meetings were published in four volumes entitled Determinants of Infant Behaviour (1961, 1963, 1965, and 1969, edited by Brian Foss).

\section{The Baltimore Project}

In 1963, while still pondering the data from the Ganda study, Mary Ainsworth embarked on a second observational project whose thoroughness no researcher has since equaled. Again, she opted for naturalistic observations, hut with interviews playing a somewhat lesser role. The 26 participating Baltimore families were recruited before their babies were horn, with 18 home visits beginning in the baby's first month and ending at 54 weeks of age. Each visit lasted 4 hours to 
make sure that mothers would feel comfortable enough to follow their normal routine, resulting in approximately 72 hours of data collection per family.

Raw data took the form of narrative reports, jotted down in personal shorthand, marked in 5-minute intervals, and later dictated into a tape recorder for transcription. Typed narratives from all visits for each quarter of the first year of life were grouped together for purposes of analysis.

A unique (at the time) aspect of Ainsworth's methodology was the emphasis on meaningful behavioral patterns in context, rather than on frequency counts of specific behaviors, This approach had roots in her dissertation work, in which she classified patterns of familial and extrafamilial dependent and independent security, in her expertise with the Rorschach test, and in her work at the Tavistock Institute with Bowlby and Robertson.

Close examination of the narratives revealed the emergence of characteristic mother-infant interaction patterns during the first 3 months (see Ainsworth et al., 1978; see also Ainsworth, 1982, 1983). Separate analyses were conducted on feeding situations (Ainsworth \& Bell, 1969), mother-infant face-to-face interaction (Blehar, Lieberman, \& Ainsworth, 1977), crying (Bell \& Ainsworth, 1972), infant greeting and following (Stayton \& Ainsworth, 1973), the attachmentexploration balance (Ainsworth, Bell, \& Stayton, 1971), obedience (Stayton, Hogan, \& Ainsworth, 1973), close bodily contact (Ainsworth, Bell, Blehar, \& Main, 1971), approach behavior (Tracy, Lamb, \& Ainsworth, 1976), and affectionate contact (Tracy \& Ainsworth, 1981).

Striking individual differences were observed in how sensitively, appropriately, and promptly mothers responded to their infants' signals. For some mother-infant pairs, feeding was an occasion for smooth cooperation. Other mothers had difficulties in adjusting their pacing and behavior to the baby's cues. In response, their babies tended to struggle, choke, and spit up, hardly the sensuous oral experience Freud had had in mind. Similar distinctive patterns were observed in face-to-face interactions between mother and infant during the period from 6 to 15 weeks (Blehar et al, 1977). When mothers meshed their own playful behavior with that of their babies, infants responded with joyful bouncing, smiling, and vocalizing. However, when mothers initiated face-to-face interactions silently and with an unsmiling expression, ensuing interactions were muted and brief. Findings on close bodily contact resembled those on feeding and 
face-to-face Interaction, as did those on crying. There were enormous variations in how many crying episodes a mother ignored and how long she let the baby cry. In countering those who argued that maternal responsiveness might lead to "spoiling," Bell and Ainsworth (1972) concluded that "an infant whose mother's responsiveness helps him to achieve his ends develops confidence in his own ability to control what happens to him" (p. 1188).

Maternal sensitivity in the first quarter was associated with more harmonious mother-infant relationships In the fourth quarter. Babies whose mothers had been highly responsive to crying during the early months now tended to cry less, relying for communication on facial expressions, gestures, and vocalizations (Bell \& Ainsworth, 1972). Similarly, infants whose mothers had provided much tender holding during the first quarter sought contact less often during the fourth quarter, hut when contact occurred, it was rated as more satisfying and affectionate (Ainsworth, Bell, Blehar, et al,, 1971), Ainsworth (Ainsworth et al., 1978) explains these findings by recourse to infants' expectations, based on prior satisfying or rejecting experiences with mother.

All first-quarter interactive patterns were also related to infant behavior in a laboratory procedure known as the Strange Situation (Ainsworth \& Wittig, 1969). This initially very controversial laboratory procedure for 1 -year-olds was originally designed to examine the balance of attachment and exploratory behaviors under conditions of low and high stress, a topic in which Harlow (196!) had aroused Ainsworth's interest during meetings of the Tavistock group, but which also reminded her of an earlier study by Arsenian (1943) on young children in an insecure situation and of her dissertation work on security theory.

The Strange Situation is a 20-minute miniature drama with eight episodes. Mother and infant are introduced to a laboratory playroom, where they are later joined by an unfamiliar woman. While the stranger plays with the baby, the mother leaves briefly and then returns. A second separation ensues during which the baby is completely alone. Finally, the stranger and then the mother return.

As expected, Ainsworth found that infants explored the playroom and toys more vigorously in the presence of their mothers than after a stranger entered or while the mother was absent (Ainsworth \& Bell, 1970). Although these results were theoretically interesting, Ainsworth became much more intrigued with unexpected patterns of infant reunion behaviors, which 
reminded her of responses Robertson had documented in children exposed to prolonged separations, and about which Bowlby (1959) had theorized in his paper on separation.

A few of the I -year-olds from the Baltimore study were surprisingly angry when the mother returned after a 3-minute (or shorter) separation. They cried and wanted contact but would not simply cuddle or "sink in" when picked up by the returning mother. Instead, they showed their ambivalence by kicking or swiping at her. Another group of children seemed to snub or avoid the mother on reunion, even though they had often searched for her while she was gone. Analyses of home data revealed that those infants who had been ambivalent toward or avoidant of the mother on reunion in the Strange Situation had a less harmonious relationship with her at home than those (a majority) who sought proximity, interaction, or contact on reunion (Ainsworth, Bell, \& Stayton, 1974). Thus originated the well-known Strange Situation classification system (Ainsworth et al., 1978), which, to Ainsworth's chagrin, has stolen the limelight from her observational findings of naturalistic mother-infant interaction patterns at home.

\section{The First Volume in the Attachment Trilogy: Attachment and Ethology}

While Ainsworth wrote up the findings from her Ganda study for Infancy in Uganda (1967) and was engaged in collecting data for the Baltimore project, Bowlby worked on the first volume of the attachment trilogy, Attachment (1969). When he began this enterprise in 1962, the plan had been for a single hook. However, as he explains in the preface: "As my study of theory progressed it was gradually borne in upon me that the field I had set out to plough so light-heartedly was no less than the one Freud had started tilling sixty years earlier." In short, Bowlby realized that he had to develop a new theory of motivation and behavior control, built on up-to-date science rather than the outdated psychic energy model espoused by Freud.

In the first half of Attachment, Bowlby lays the groundwork for such a theory, taking pains to document each important statement with available research findings. He begins by noting that organisms at different levels of the phylogenetic scale regulate instinctive behavior in distinct ways, ranging from primitive reflex-like "fixed action patterns" to complex plan hierarchies with subgoals. In the most complex organisms, instinctive behaviors may be "goal-corrected" with continual on-course adjustments (such as a bird of prey adjusting its flight to the movements of the prey). The concept of cybernetically controlled behavioral systems organized as plan 
hierarchies (Miller, Galanter, \& Pribram, 1960) thus came to replace Freud's concept of drive and instinct. Behaviors regulated by such systems need not be rigidly innate, hut-depending on the organism- can adapt in greater or lesser degrees to changes in environmental circumstances, provided that these do not deviate too much from the organism's environment of evolutionary adaptedness. Such flexible organisms pay a price, however, because adaptable behavioral systems can more easily be subverted from their optimal path of development. For humans, Bowlby speculates, the environment of evolutionary adaptedness probably resembles that of present-day hunter-gatherer societies.

The ultimate functions of behavioral systems controlling attachment, parenting, mating, feeding, and exploration are survival and procreation. In some cases, the predictable outcome of system activation is a time-limited behavior (such as food intake); in others it is the time-extended maintenance of an organism in a particular relation to its environment (e.g., within its own territory or in proximity to particular companions).

Complex behavioral systems of the kind proposed by Bowlby can work with foresight in organisms that have evolved an ability to construct internal working models of the environment and of their own actions in it (a concept taken over from (Craik, 1943, through the writings of the biologist J. Young, 1964). The more adequate an organism's internal working model, the more accurately the organism can predict the future, However, adds Bowlby, if working models of the environment and self are out of date or are only half revised after drastic environmental change, pathological functioning may ensue. He speculates that useful model revision, extension, and consistency checking may require conscious processing of model content. In humans, communicative processes-initially limited to emotional or gestural signaling and later including language - also permit the inter-subjective sharing of model content. On an intrapsychic level, the same processes are useful for self-regulation and behavioral priority setting.

In mammals and birds, behavioral systems tend to become organized during specific sensitive developmental periods. As initial reflex-like behavior chains come under more complex, cybernetically controlled organization, the range of stimuli that can activate them also becomes more restricted, This is the case in imprinting, broadly defined as the restriction of specific instinctive behaviors to particular individuals or groups of individuals during sensitive phases of 
development, as in filial, parental, and sexual imprinting.

Having laid out this general theory of motivation and behavior regulation in the first half of the volume, Bowlby goes on, in the second half, to apply these ideas to the specific domain of infant-mother attachment. He defines attachment behavior as behavior that has proximity to an attachment figure as a predictable outcome and whose evolutionary function is protection of the infant from danger, insisting that attachment has its own motivation and is in no way derived from systems subserving mating and feeding.

Although human infants initially direct proximity-promoting signals fairly indiscriminately to all caregivers, these behaviors become increasingly focused on those primary figures who are responsive to the infant's crying and who engage the infant in social interaction (Schaffer \& Emerson, 1964). Once attached, locomotor infants are able to use the attachment figure as a secure base for exploration of the environment and as a safe haven to which to return for reassurance (Ainsworth, 1967; Schaffer \& Emerson, 1964). How effectively the attachment figure can serve in these roles depends on the quality of social interaction-especially the attachment figure's sensitivity to the infant's signals-although child factors also play a role. Building on Ainsworth's Ganda study (1967) and preliminary findings from her Baltimore project, Bowlby (1969) comments that:

when interaction between a couple runs smoothly, each party manifests intense pleasure in the other's company and especially in the other's expression of affection. Conversely, whenever interaction results in persistent conflict each party is likely on occasion to exhibit intense anxiety or unhappiness, especially when the other is rejecting. Proximity and affectionate interchange are appraised and felt as pleasurable by both, whereas distance and expressions of rejection are appraised as disagreeable or painful by both. (p. 242)

During the preschool years, the attachment behavioral system, always complementary to the parental caregiving system, undergoes further reorganization as the child attains growing insight into the attachment figure's motives and plans. Bowlby refers to this stage as goalcorrected partnership. However, in emphasizing infant initiative and sensitive maternal responding, Bowlby's (1951) earlier theorizing on the mother as the child's ego and superego was regrettably lost.

\section{Consolidation}


The publication of the first volume of the attachment trilogy in 1969 coincided with the appearance in print of initial findings from Ainsworth's Baltimore project (reviewed earlier). However, many investigators strongly contested Ainsworth's claims regarding the meaning of Strange Situation behavior, often because they failed to note that Strange Situation classifications had been validated against extensive home observations. Some interpreted avoidant infants' behavior as independence. The controversy lessened somewhat after the publication of Patterns of Attachment (Ainsworth et al., 1978), which drew together the results from the Baltimore project and presented findings from other laboratories on the sequelae of attachment classifications in toddlerhood and early childhood (e.g., Main, 1973; Matas, Arend, \& Sroufe, 1978).

During this period, many of Ainsworth's graduate students began to publish their own work. Silvia Bell (1970) examined the relationship between object permanence and attachment. Mary Main (1973) studied secure and insecure toddlers' capacity to become invested in play activities and problem solving. Mary Blehar (1974) undertook the first study of attachment and nonmaternal care, and Alicia Lieberman (1977) investigated attachment and peer relationships in preschoolers. Mary Ainsworth's influence is also evident in the fact that many Johns Hopkins undergraduate students who had helped with the analysis of data from the Baltimore project later produced innovative dissertations on attachment-related topics at their respective graduate institutions. Among these students were Robert Marvin (1972, 1977), who wrote on the goal-corrected partnership; Milton Kotelchuck (1972), who studied father attachment; Mark Cummings (1980), who investigated attachment and day care; Mark Greenberg (Greenberg \& Marvin, 1979), who examined attachment in deaf children; and Everett Waters (1978), who documented the longitudinal stability of attachment patterns from 12 to 18 months.

Everett Waters' entry into graduate study at the University of Minnesota in 1973 had a profound effect on Alan Sroufe, who had read Mary Ainsworth's (1968) theoretical article about object relations and dependency but had not heard of the Strange Situation or the Baltimore project (Sroufe, personal communication, 1988). Sroufe's contact with Waters led to significant empirical and theoretical collaborations. In 1977, Sroufe and Waters wrote an influential paper that made attachment as an organizational construct accessible to a large audience. At the same time, Sroufe and Egeland, together with many of their students, undertook a large-scale longitudinal 
study of attachment with an at-risk population (disadvantaged mothers), The Minnesota study, summarized in Sroufe (1983) but still ongoing, stands as the second major longitudinal study of the relationship between quality of caregiving and security of attachment.

Elsewhere across the United States, much time was spent testing the predictive validity of Strange Situation reunion classifications. Many researchers sought to train with Mary Ainsworth or her former students to learn the procedure and classification system. Hundreds of studies using the Strange Situation appeared in print. It often seemed as if attachment and the Strange Situation had become synonymous.

\section{ATTACHMENT THEORY AND MENTAL REPRESENTATION}

Separation (Bowlby, 1973) and Loss (Bowlby, 1980a), the second and third volumes in Bowlby's attachment trilogy, were slower to make an impact on the field of developmental psychology than the first volume, in part because relevant empirical studies lagged behind. Like Attachment, these two volumes cover much more theoretical ground that their titles imply.

\section{Separation}

In this book, Bowlby (1973) revises Freud's (1926/1959) theory of signal anxiety, lays out a new approach to Freud's (1923/1961, 1940/1964) motivational theories, and presents an epigenetic model of personality development inspired by Waddington's (1957) theory of developmental pathways.

Elaborating on his seminal 1959 paper, Bowlby notes that two distinct sets of stimuli elicit fear in children: the presence of unlearned and later of culturally acquired clues to danger and/or the absence of an attachment figure. Although escape from danger and escape to an attachment figure commonly occur together, the two classes of behavior are governed by separate control systems (observable when a ferocious dog comes between a mother and her young child.

Although Bowlby regarded the systems controlling escape and attachment as conceptually distinct, he considers both as members of a larger family of stress-reducing and safety-promoting behavioral systems, whose more general function is that of maintaining an organism within a defined relationship to his or her environment. Rather than striving for stimulus absence, as Freud had suggested, Bowlby posits that humans are motivated to maintain a dynamic balance between 
familiarity-preserving, stress-reducing behaviors (attachment to protective individuals and to familiar home sites, retreat from the strange and novel) and antithetical exploratory and information-seeking behaviors.

After revising Freud's theories of fear and motivation, Bowlby reexamined Freud's concept of the "inner world" in light of modern cognitive theory. In Separation, he expands ideas proposed in Attachment by suggesting that, within an individual's internal working model of the world, working models of self and attachment figure are especially salient. These working models, acquired through interpersonal interaction patterns, are complementary. If the attachment figure has acknowledged the infant's needs fur comfort and protection while simultaneously respecting the infant's need for independent exploration of the environment, the child is likely to develop an internal working model of self as valued and reliable. Conversely, if the parent has frequently rejected the infant's bids for comfort or for exploration, the child is likely to construct an internal working model of self as unworthy or incompetent. With the aid of working models, children predict the attachment figure's likely behavior and plan their own responses. What type of model they construct is therefore of great consequence.

In Separation, Bowlby also elucidates the role of internal working models in the intergenerational transmission of attachment patterns. Individuals who grow up to become relatively stable and self-reliant, he postulates, normally have parents who are supportive when called upon, hut who also permit and encourage autonomy. Such parents tend not only to engage in fairly frank communication of their own working models of self, of their child, and of others, hut also indicate to the child that these working models are open to questioning and revision. For this reason, says Bowlby, the inheritance of mental health and of ill health through family micro-culture is no less important, and may well he far more important, than is genetic inheritance (Bowlby, 973, p. 323).

\section{Loss}

In the third volume of the attachment trilogy, Bowlby (1980a) uses information-processing theories to explain the increasing stability of internal working models as well as their defensive distortion. The stability of internal working models derives from two sources: (a) patterns of interacting grow less accessible to awareness as they become habitual and automatic, and (b) dyadic patterns of relating are more resistant to change than individual patterns because of 
reciprocal expectancies.

Given that old patterns of action and thought guide selective attention and information processing in new situations, some distortion of incoming information is normal and unavoidable. The adequacy of internal working models can be seriously undermined, however, when defensive exclusion of information from awareness interferes with their updating in response to developmental and environmental change.

To explain the workings of defensive processes, Bowlby cites evidence showing that incoming information normally undergoes many stages of processing before reaching awareness (see Dixon, 1971; Erdelyi, 1974) At every stage, some information is retained for further processing and the remainder discarded. That this may happen even after information has already undergone very advanced levels of encoding is shown by dichotic listening studies, In these studies, individuals who are presented with different messages to each ear through headphones are able to selectively attend to one of them. That the unattended message is nevertheless receiving high level processing becomes obvious when the person becomes alerted to a word of personal significance (e.g., the person's name) that has been inserted into the unattended message.

Bowlby proposes that defensive exclusion of information from awareness derives from the same processes as selective exclusion, although the motivation for the two types of exclusion differs. Three situations are believed to render children particularly prone to engaging in defensive exclusion: situations that parents do not wish their children to know about even though the children have witnessed them, situations in which the children find the parents' behavior too unbearable to think about, and situations in which children have done or thought about doing something of which they are deeply ashamed.

Although defensive exclusion protects the individual from experiencing unbearable mental pain, confusion, or conflict, it is hound to interfere with the accommodation of internal working models to external reality. Indeed, a number of clinical studies reviewed in Separation (e.g., Cain $\&$ Fast, 1972) suggest that defensive exclusion leads to a split in internal working models. One set of working models- accessible to awareness and discussion and based on what a child has been told-represents the parent as good and the parent's rejecting behavior as caused by the "badness" 
of the child, The other model, based on what the child has experienced but defensively excluded from awareness, represents the hated or disappointing side of the parent.

In Loss, Bowlby attempts to shed further light on these repressive and dissociative phenomena with the aid of Tulving's (1972) distinction between episodic and semantic memory. According to Tulving, autobiographical experience is encoded in episodic memory, whereas generic propositions are stored in semantic memory, with each memory system possibly using distinct storage mechanisms. Generic knowledge may derive from information supplied by others and from actual experience. Bowlby surmises that severe psychic conflict is likely to arise when the two sources of stored information (generalizations built on actual experience and on communications from others) are highly contradictory. In such cases, defensive exclusion may be brought to bear on episodic memories of actual experience. According to Bowlby, such processes are especially likely in bereaved children under 3 years of age.

Finally, in Loss, Bowlby also considers a more complex related prob1cm, namely, the control of simultaneously active behavioral systems. In Attachment and Separation, the interplay among behavioral systems was implicitly treated as one of competition, not higher level regulation (see also Bretherton \& Ainsworth, 1974). In Loss, Bowlby posits an executive structure that takes the place of Freud's (1923/1961) concept of ego. The central nervous system, Bowlby suggests, is organized in a loosely hierarchical way, with an enormous network of two-way communications among subsystems. At the top of the hierarchy, he posits one or perhaps several principal evaluators or controllers, closely linked to long-term memory. Their task is to scan incoming information for relevance. If evaluated as relevant, it may be stored in short-term memory to select aspects thereof for further processing.

Conscious processing is likely to facilitate high-level activities such as categorizing, retrieving, comparing, framing plans, and inspection of overlearned, automated action systems. In a unified personality, Bowlby claims, the principal system or systems can access all memories in whatever type of storage they are held. However, in some cases, the principal system or systems may nor be unified or capable of unimpeded intercommunication with all subsystems. In this case, particular behavioral systems may not he activated when appropriate, or signals from these behavioral systems may not become conscious, although fragments of defensively excluded 
information may at times seep through.

Some of the dissociative or repressive phenomena involved in the deactivation of the attachment system occur during pathological mourning. For example, complete or partial disconnection of an emotional response from its cause is frequent. When the disconnection is only partial, emotional responses may be directed away from the person who caused them to third persons or to the self. I knee, a bereaved person may become morbidly preoccupied with personal reactions and sufferings, rather than attributing his or her feelings to the loss of a close relationship. Similarly, in disordered mourning, a bereaved person's disposition toward compulsive caregiving may derive from the redirection of attachment behavior. The individual may he taking the role of attachment figure instead of seeking care.

\section{Attachment and Therapy}

This discussion of defensive processes leads into the topic that preoccupied Bowlby during the last 10 years of his life: the uses of attachment theory in psychotherapy (Bowlby, 1988), Under attachment theory, a major goal in psychotherapy is the reappraisal of inadequate, outdated working models of self in relation to attachment figures, a particularly difficult task if important others, especially parents, have forbidden their review. As psychoanalysts have repeatedly noted, a person with inadequate, rigid working models of attachment relations is likely to inappropriately impose these models on interactions with the therapist (a phenomenon known as transference). The joint task ${ }_{0} \mathrm{f}$ therapist and client is to understand the origins of the client's dysfunctional internal working models of self and attachment figures, Toward this end, the therapist can be most helpful by serving as a reliable, secure base from which an individual can begin the arduous task of exploring and reworking his or her internal working models.

\section{NEW DIRECTIONS}

Currently, attachment theory and research are moving forward along several major fronts, inspired by the second and third volumes of Bowlby's attachment trilogy, by methodological advances, and by the infusion into attachment theory of complementary theoretical perspectives.

\section{Attachment and Representation}

As a result of Mary Main's Berkeley study (Main, Kaplan, \& Cassidy, 1985) and, I think, the 
publication of the Society for Research in Child Development Monograph, Growing Points of Attachment Theory and Research (Bretherton \& Waters, 1985), we are now beginning to empirically explore the psychological, internal, or representational aspects of attachment, including the intergenerational transmission of attachment patterns that had been at the center of Bowlby's interests since his beginnings in psychiatry but that are most clearly elaborated in volumes 2 and 3 of the attachment trilogy (see Bretherton, 1987, 1990, 1991).

Interestingly, an additional source of inspiration for the study of internal working models came from attempts to translate Ainsworth's infant- mother attachment patterns into corresponding adult patterns. in the Adult Attachment Interview (George, Kaplan, \& Main, 1984; Main \& Goldwyn, in press), parents were asked open-ended questions about their attachment relations in childhood and about the influence of these early relations on their own development. Three distinct patterns of responding were identified: Autonomous-secure parents gave a clear and coherent account of early attachments (whether these had been satisfying or not); preoccupied parents spoke of many conflicted childhood memories about attachment but did not draw them together into an organized, consistent picture; and, finally, dismissing parents were characterized by an inability to remember much about attachment relations in childhood. In some of the dismissing interviews, parents' parents were idealized on a general level, hut influences of early attachment experiences on later development were denied. Specific memories, when they did occur, suggested episodes of rejection.

Not only did the Adult Attachment Interview classifications correspond to Ainsworth's secure, ambivalent, and avoidant infant patterns at a conceptual level, but adult patterns were also empirically correlated with infant patterns (e.g., a dismissing parent tended to have an avoidant infant; Main \& Goldwyn, in press). These findings have since been validated for prenatally administered interviews by Fonagy, Steele, and Steele (1991) and by Ward et al. (1990). Consonant findings were also obtained in a study of young adults in which Adult Attachment Interview classifications were correlated with peer reports (Kobak \& Sceery, 1988).

In addition, representational measures of attachment have been devised for use with children. A pictorial separation anxiety test for adolescents, developed by Hansburg (1972), was 
adapted for younger children by Klagsbrun and Bowlby (1976) and more recently revised and validated against observed attachment patterns by Kaplan (1984) and Slough and Greenberg (1991) Likewise, attachment-based doll story completion tasks for preschoolers were validated against behavioral measures by Bretherton, Ridgeway, and Cassidy (1990) and Cassidy (1988). In these tests, emotionally open responding tended to be associated with secure attachment classifications or related behaviors.

Finally, several authors have created interviews that examine attachment from the parental as opposed to the filial perspective (e.g., Bretherton, Biringen, Ridgeway, Maslin, \& Sherman, 1989; George \& Solomon, 1989). In addition, Waters and Q-sort that can be used to assess a mother's internal working models of her child's attachment to her.

\section{Attachment Across the Life Span}

A related topic, attachment relationships between adults, began in the early 1970s, with studies of adult bereavement (Bowlby \& Parkes, 1970; Parkes, 1972) and marital separation (Weiss, 1973, 1977). More recently, interest in adult attachments has broadened to encompass marital relationships (Weiss, 1982, 1991) and has taken a further upsurge with work by Shaver and Hazan (1988), who translated Ainsworth's infant attachment patterns into adult patterns, pointing out that adults who describe themselves as secure, avoidant, or ambivalent with respect to romantic relationships report differing patterns of parent-child relationships in their families of origin. Finally, Cicirelli $(1989,1991)$ has applied attachment theory to the study of middle-aged siblings and their elderly parents. Much future work will be needed to delineate more fully the distinct qualities of child-adult, child-child, and adult-adult attachment relationships (see Ainsworth, 1989), as well as their interplay within the family system, a task begun by Byng-Hall (1985) and Marvin and Stewart (1990),

\section{Attachment and Developmental Psychopathology}

Attachment theory and research are also making a notable impact on the emerging field of

developmental psychopathology (Sroufe, 1988), with longitudinal attachment-based studies of families with depression (Radke-Yarrow, Cummings, Kuczinsky, \& Chapman, 1985), of families with maltreatment (e.g., Cicchetti \& Barnett, 1991; Crittenden, 1983; Schneider-Rosen, Braunwald, Carlson, \& Cicchetti, 1985), and of clinical interventions in families with low social support 
(Lieberman \& Pawl, 1988; Spieker \& Booth, 1988) and with behavior-problem children (Greenberg \& Speltz, 1988). Much of this work is represented in a volume on clinical implications of attachment (Belsky \& Nezworski, 1988). These topics hark back to Bowlby's seminal ideas from the 1930s, but they have been greatly enriched by Mary Ainsworth's notions on the origins of individual differences of attachment patterns.

\section{The Ecology of Attachment}

Although we have made progress in examining mother-child attachment, much work needs to he done with respect to studying attachment in the microsystem of family relationships (Bronfenbrenner, 1979). Despite studies by Belsky, Gilstrap, and Rovine (1984), Lamb (1978), and Parke and Tinsley (1987) that show fathers to be competent, if sometimes less than fully participant attachment figures, we still have much to learn regarding father attachment. Another important topic, sibling attachment, has been tackled by a few researchers (e.g., Stewart \& Marvin, 1984; Teti \& Ablard, 1989), but triadic studies of attachment relationships (modeled on Dunn, 1988) are sorely lacking. Especially crucial are attachment-theoretic studies of loyalty conflicts, alliances by a dyad vis-a-vis a third family member, and enmeshment of a child in the spousal dyad, as exemplified in a report by Fish, Belsky, and Youngblade (1991) in which insecure attachment in infancy was associated with inappropriate involvement in spousal decisionmaking at 4 years of age. Finally, the interrelations of child temperament and developing attachment relationships with other family members remain conceptually unclear despite intensive research efforts (Belsky \& Rovine, 1987; Sroufe, 1985).

The documentation of family and social network factors as they affect attachment relations (e.g., Belsky \& Isabella, 1988; Belsky, Rovine, \& Taylor, 1984) has been more successful. In the Pennsylvania project, attachment quality at the end of the first year was predictable from relative changes in levels of marital satisfaction after the child's birth, as well as from parental satisfaction with social support, hut not its frequency.

An ecological perspective also calls for an examination of issues related to dual-worker families, especially in view of the continued sex/gender differentiation of parenting. Some feminist theorists have interpreted attachment theory as supporting the traditional view of women as primary caregivers (Chodorow, 1978; Johnson, 1988). This is not strictly justified, because 
attachment theory does not specify that caregiving must be done by mothers or be restricted to females (Marris, 1982), Most central to healthy development, according to attachment theory, is infants' need for a committed caregiving relationship with one or a few adult figures. Although the majority of attachment studies have focused on mothers because mothers tend to fill this role most often, we do have evidence that infants can he attached to a hierarchy of figures, including fathers, grandparents, and siblings (Schaffer \& Emerson, 1964), as well as to day-care providers (Howes, Rodning, Galuzzo, \& Myers, 1988). However, our knowledge about the range of societal options for successfully sharing the task of bringing up children is still woefully inadequate. The recent spate of studies documenting an increased risk of insecure attachment if day care begins in the first year and is extensive in duration (Belsky \& Rovine, 1988; Belsky \& Braungart, 1991) is worrisome and needs resolution. Cross-cultural studies of attachment and nonparental care in countries such as Sweden and Israel may ultimately provide more reliable answers.

\section{Cross-Cultural Studies}

Moving from family and other social networks to the larger societal matrix, we find that studies of Strange Situation classifications in other cultures have sparked a lively debate on their universal versus culture-specific meaning. in a north German study, avoidant classifications were overrepresented (Grossmann, Grossmann, Spangler, Suess, \& Unzner, 1985), whereas ambivalent classifications were more frequent than expected in Israeli kibbutzim (Sagi et al., 1985) and in Japan (Miyake, Chen, \& Campos, 1985).

Initially, these findings were interpreted in purely cultural terms. Thus, Grossmann et al. (1985) proposed that the high incidence of avoidant infants in Germany should be attributed not to parental rejection, hut rather to a greater parental push toward infants' independence. Similarly, the high frequency of ambivalent classifications observed in Israeli kibbutzim and Japan was attributed to underexposure to strangers (Miyake et al., 1985; Sagi et al., 1985). Though

persuasive on the surface, these explanations were not based on systematic assessments of parental beliefs and culturally guided practices.

More recently, van Ijzendoorn and Kroonenberg (1988) examined the frequency distributions of Strange Situation classifications from over a thousand U.S. and cross-national studies, 
pointing out that valid conclusions about cross-national differences should not be drawn from single samples. In addition, intercorrelational patterns of home and Strange Situation behavior in north Germany (Grossmann et al., 1985) closely resembled those in the Ainsworth's Baltimore study, at least in part undermining a purely cultural interpretation. Likewise, Sagi, Aviezer, Mayseless, Donnell, and Joels (1991) attribute the abundance of ambivalent classifications to specific nighttime caregiving arrangements in the kibbutzim they studied, rather than fewer experiences with strangers. Taken in combination, these findings suggest that Strange Situation classifications, and hence the concept of parental sensitivity, may have more cross-cultural validity in industrialized nations than was initially believed, hut the issue is by no means resolved.

Systematic work on the more fascinating topic of how different cultures-especially nonWestern cultures-fit attachment behaviors and relationships into their overall social organization has barely begun. There are, however, some tantalizing hints in the ethnographic literature (see Bretherton, 1985, for a review). For example, the Micronesian society of Tikopia (Firth, 1936) deliberately fosters attachment between an infant and its maternal uncle by prescribing face-toface talk with the infant on a regular basis. This maternal uncle is destined to play an important quasi-parental role in the life of the child. Along somewhat different lines, Balinese mothers control their infants' exploratory behavior by using fake fear expressions to bring the infants back into close proximity to them (Bateson \& Mead, 1942). In both cultures, a biological system is molded to a particular society's purposes (by fostering specific relationships or controlling exploration).

A recent study of parent-infant attachment among the Efe begins to provide systematic information in this area. The Efe, a semi-nomadic people, live in the African rain forest, subsisting on foraging, horticulture, and hunting (Tronick, Winn, \& Morelli, 1985). Young Efe infants receive more care (including nursing) from other adult women than from their own mother, except at night. Despite this multiple mothering system, by 6 months, infants begin to insist on a more focalized relationship with their own mothers, although other female caregivers continue to play a significant role. Tronick et al. attributed Efe practices to their living arrangements, with closely spaced dwellings that offer little privacy and that make cooperation and sharing highly valued behaviors. In sum, attachment behavior is heavily overlain with cultural prescriptions, even 
in a society that much more closely resembles the conditions of human evolution than our own. To better explore such cultural variations in attachment organization attachment researchers need to develop ecologically valid, theory-driven measures, tailored to specific cultures and based on a deeper knowledge of parents' and children's culture-specific folk theories about family relationships and attachment.

\section{Attachment and Public Policy}

Cultural differences in the regulation of attachment behaviors raise important questions about the value diverse societies place on attachment relations. In a thought-provoking chapter, Marris (1991) points to the fundamental tension between the desire to create a secure and predictable social order and the desire to maximize one's own opportunities at the expense of others. A good society, according to Marris, would he one which, as far as is humanly possible,

minimizes disruptive events, protects each child's experience of attachment from harm, and supports family coping. Yet, in order to control uncertainty, individuals and families are tempted to achieve certainty at the expense of others (i.e., by imposing a greater burden of uncertainty on them or by providing fewer material and social resources). When powerful groups in society promote their own control over life circumstances by subordinating and marginalizing others, they make it less possible for these groups to offer and experience security in their own families. Valuing of attachment relations thus has public policy and moral implications for society, not just psychological implications for attachment dyads. This brings me hack to one of Bowlby's early statements:

"If a community values its children it must cherish their parents" (Bowlby, 1951, p. 84).

\section{CHALLENGING TASKS FOR ATTACHMENT THEORY}

In the preceding section, I have outlined the many new directions into which attachment research is branching out. It is difficult to predict which of these efforts will he most fruitful. No doubt, additions, revisions, and challenges to the theory will continue to arise our of future em-

pirical studies. In this final section, however, I would like to focus briefly on some of the theoretical tasks that lie ahead. The idea that human motivation derives from an interplay of familiarityand novelty-seeking systems needs further exploration, as does the notion that the human personality can be conceptualized as a hierarchy of interlinked systems. New theoretical treatments 
of defensive processes in the construction of internal working models of attachment need to he worked out in relation to insights from representational theories and research, and clinical attachment theory requires the development of an experiential language akin to that used by other psychoanalytic theories of interpersonal relatedness, such s Winnicott (1965) and Sullivan (1953). Most important, in my view, is that the development of internal working models of self and other within-attachment relationsshould be studied in conjunction with new approaches to the "dialogic" or "narrative" self, integrating the mental health perspective of attachment theory with the perspective of theorists interested in the social construction of reality (Hermans, Kempen, \& van Loon, 1992).

These theoretical developments must go hand in hand or be followed by new methodological developments. Without Mary Ainsworth's work on patterns of attachment in the Strange Situation and Mary Main's Adult Attachment Interview that built on them, Bowlby's theoretical contributions to developmental and clinical psychology would not have had their current influence. I predict that, in the future, attachment theory may provide the underpinnings of a more general theory of personality organization and relationship development. Such a theory would build on, hut also go beyond, Bowlby's reworking of Freud's ideas on motivation, emotion, and development.

In formulating the basic tenets of attachment theory, Bowlby's strategy was, wherever possible, to meticulously test intuitive hunches against available empirical findings and concepts from related domains, thus keeping the theory open to change. In his last work, a biography of Charles Darwin, Bowlby may have been talking about himself when he said of Darwin:

Since causes are never manifest, the only way of proceeding is to propose a plausible theory and then test its explanatory powers against further evidence, and in comparison with the power of rival theories.... Since most theories prove to be untenable, advancing them is a hazardous business and requires courage, a courage Darwin never lacked. (Bowlby, 1991, p. 412)

Bowlby and Ainsworth, too, did not lack that courage. To explore the full future potential of attachment theory, others will need to exercise similar courage in refining, extending, and challenging it.

\section{REFERENCES}

Ainsworth, M. D. S. (1963). The development of infant-mother interaction among the Ganda. In B. M. Foss (Ed.), Determinants of infant behavior (pp. 67-104). New York: Wiley. 
Ainsworth, M. D. S. (1967), Infancy in Uganda: Infant care and the growth of love, Baltimore: Johns Hopkins University Press,

Ainsworth, M. D. S. (1968), Object relations, dependency, and attachment: A theoretical review of the infant mother relationship. Child Development, 40, 969-1025.

Ainsworth, M. 1). S. (1974). Citation for the G. Stanley Hall Award to John Bowlby. Unpublished manuscript.

Ainsworth, M. D. S. (1982). Attachment: Retrospect and prospect. In C. M. Parkes \& J. Stevenson-Hinde (Eds.), The place of attachment in human behavior (pp. 3-30). New York: Basic Books.

Ainsworth, M. D. S. (1983). A sketch of a career. In A. N. O’Connoll \& N. F. Russo (Eds.), Models of achievement: Reflections of eminent women in psychology (pp. 200-219). New York: Columbia University Press,

Ainsworth, M. D. S. (1989). Attachments beyond infancy. American Psychologist, 44, 709-716.

Ainsworth, M. D. S., \& Bell, S. M. (1969). Some contemporary patterns in the feeding situation. In A. Ambrose (Ed,), Stimulation in early infancy (pp. 133-170). London: Academic Press.

Ainsworth, M. D. S., \& Bell, S. M. (1970). Attachment, exploration, and separation: Illustrated by the behavior of one-year-olds in a strange situation. Child Development, 41, 49-67.

Ainsworth, M. D. S., Bell, S. M., Blehar, M. C., \& Main, M. (1971, April). Physical contact: A study of infant responsiveness and its relation to maternal handling. Paper presented at the biennial meeting of the Society for Research in Child Development, Minneapolis, MN.

Ainsworth, M. D. S., Bell, S. M., \& Stayton, D. (1971). Individual differences in Strange Situation behavior of one-year-olds. In H. R. Schaffer (Ed,), The origins of human social relations (pp. 17-57). London: Academic Press.

Ainsworth, M. D. S., Bell, S. M., \& Stayton, D. (1974). Infant-mother attachment and social development. In M. P. Richards (Ed.), The introduction of the child into a social world (pp. 99-135). London: Cambridge University Press.

Ainsworth, M. 1). S., Blehar, M. C., Waters, E., \& Wall, 5. (1978). Patterns of attachment: A psychological study of the Strange Situation. Hillsdale, NJ: Erlbaum.

Ainsworth, M. D. S., \& Bowlby, J. (1991), An ethological approach to personality development. American Psychologist, 46, 331-341.

Ainsworth, M. I). S., \& Wittig, B. A. (1969). Attachment and the exploratory behaviour of one-year-olds in a strange situation. In B. M. Foss (Ed.), Determinants of infant behaviour (Vol. 4, pp. 113-136), London: Methuen.

Ambrose, J. A. (1961), The development of the smiling response in early human infancy: An experimental and theoretical study of their course and significance. Unpublished doctoral dissertation, University of London.

Arsenian, J. M. (1943). Young children in an insecure situation. Journal of Abnormal and Social Psychology, 38, 225-229.

Bateson, G., \& Mead, M. (1942). Balinese character: A photographic analysis. New York: 
New York Academy of Sciences.

Bell, S. M. (1970). The development of the concept of the object as related to infant-mother attachment. Child Development, 41, 291-311.

Bell, S. M,, \& Ainsworth, M. D. S. (1972). Infant crying and maternal responsiveness. Child Development, 43, 1171-1190.

Belsky, J., \& Braungart, 3, M. (1991). Are insecure-avoidant infants with extensive day-care experience less stressed by and more independent in the Strange Situation? Child Development, 62, 567- 571.

Belsky, J., Gllstrap, B., \& Rovine, M. (1984). The Pennsylvania Infant and Family Development Project, I: Stability and change in mother-infant and father- infant interaction in a family setting at one, three, and nine months. Child Development, 55, 692-705.

Belsky, J, \& Isabella, R. (1988). Maternal, infant, and social-contextual determinants of attachment security. In J. Belsky \& T. Nezworski (Eds.), Clinical implications of attachment (pp. 41-94). Hillsdale, NJ: Erlbaum.

Belsky, J., \& Nezworski (1988). Clinical implications of attachment, Hillsdale, NJ: Erlbaum.

Belsky, J., \& Rovine, M. (1987). Temperament and attachment security in the Strange Situation: An empirical rapprochement. Child Development, 58, 787-795,

Belsky, J., \& Rovine, M. J. (1988). Nonmaternal care in the first year of life and the security of infant-mother attachment. Child Development, 59, 157-167.

Belsky, J., Rovine, M., \& Fish, M. (in press). The developing family system. In M. Gunnar (Ed.), Systems and development: Minnesota symposia on child development (Vol. 22). Hillsdale, NJ: Erlbaum.

Belsky, J., Rovine, M., \& Taylor, I). (1984). The Pennsylvania Infant arid Family Development Project, II: Origins of individual differences in infant-mother attachment: Maternal and infant contributions, Child Development, 55, 706-717.

Blatz, W. (1940), Hostages to peace: Parents and the children of democracy. New York: Morrow.

Blehar, M. C. (1974). Anxious attachment and defensive reactions associated with day care. Child Development, 45, 683-692.

Blehar, M. C., Lieberman, A. F., \& Ainsworth, M. D. S. (1977). Early face-to-face interaction and its relation to later infant-mother attachment. Child Development, 48, 182-194.

Bowlby, 3. (1940). The influence of early environment in the development of neurosis and neurotic character. International Journal of Psycho-Analysis, XXI, 1-25.

Bowlby, J. (1944). Forty-four juvenile thieves: Their characters and home lives. International Journal of Psycho-Analysis, XXV, 19-52.

Bowlby, J, (1949). The study and reduction of group tensions in the family. Human Relations, 2, 123-128.

Bowlby, J. (1951). Maternal care and mental health. World Health Organization Monograph 
(Serial No. 2).

Bowlby, J. (1958), The nature of the child's tie to his mother. International Journal of PsychoAnalysis, XXXIX, 1-23.

Bowlby, J. (1959). Separation anxiety. International Journal of Psycho-Analysts, XLI, 1-25.

Bowlby, J. (1960). Grief and mourning in infancy and early childhood. The Psychoanalytic Study of the Child, VX, 3-39.

Bowlby, J, (I 962a). Defences that follow loss: Causation and function. Unpublished manuscript, Tavistock Child Development Research Unit, London.

Bowlby, J. (1962b). Loss, detachment and defence. Unpublished manuscript, Tavistock Child Development Research Unit, London.

Bowlby, J. (1969), Attachment and loss, Vol. 1: Attachment. New York: Basic Books.

Bowlby, J. (1973). Attachment and loss, Vol. 2: Separation. New York: Basic Books.

Bowlby, J. (I980a). Attachment and loss, Vol. 3: Loss, sadness and depression. New York: Basic Books.

Bowlby, J. (1980b). By ethology out of psycho-analysis: An experiment in interbreeding. Animal Behavior, 28, 649-656.

Bowlby, J, (1987). Colloquium presented at the University of Virginia.

Bowlby, J. (1988). A secure base: Parent-child attachment and healthy human development. New York: Basic Books.

Bowlby, J. (1991). Charles Darwin: A new biography. London: Hutchinson.

Bowlby, J,, Ainsworth, M., Boston, M., \& Rosenbluth, D. (1956), The effects of mother-child separation: A follow-up study. British Journal of Medical Psychology, 29, 2 11-247.

Bowlby, J., \& Parkes, C. M. (1970). Separation and loss within the family. In E. J. Anthony \& C. Koupernik (Eds.), The child in his family: International Yearbook of Child Psychiatry and Allied Professions (pp. 197-216), New York: Wiley.

Bretherton, I. (1985). Attachment theory: Retrospect and prospect. In I. Bretherton \& F. Waters (Eds.), Growing points of attachment theory and research: Monographs of the Society for Research in Child Development, 50(1-2, Serial No. 209), 3-35.

Bretherton, I. (1987). New perspectives on attachment relations: Security, communication, and internal working models. In J. Osofsky (Ed.), Handbook of infant development (pp. 1061-1100), New York: Wiley.

Bretherton, 1. (1990), Open communication and internal working models: Their role in attachment relationships. In R. Thompson (Ed.), Socioemotional development (Nebraska Symposium, 1987). Lincoln, NE: University of Nebraska Press.

Bretherton, I. (1991). Pouring new wine into old bottles: The social self as internal working model. In M. R. Gunnar \& L. A. Sroufe (Eds.), Self processes and development: The Minnesota symposia on child development (Vol. 23, pp. 1 -41). Hillsdale, NJ: Erlbaum. 
Bretherton, I., \& Ainsworth, M. D. S. (1974). One-year-olds in the Strange Situation. In M. Lewis \& L. Rosenblum (Eds.), The origins of fear (pp. 134- 164), New York: Wiley.

Bretherton, I., Biringen, Z., Ridgeway, D., Maslin, M., \& Sherman, M. (1989). Attachment: The parental perspective. Infant Mental Health Journal (Special Issue), 10, 203-220.

Bretherton, I., Ridgeway, D., \& Cassidy, J. (1990). Assessing internal working models in the attachment relationship: An attachment story completion task for 3-ycar-olds. In M. T. Greenberg, D. Cicchetti, \& E. M. Cummings (Eds.), Attachment during the preschool years (pp. 272-308). Chicago: University of Chicago Press.

Bretherton, I., \& Waters, E. (1985). Growing points of attachment theory and research. Monographs of the Society for Research in Child Development, 50(1-2, Serial No, 209).

Bronfenbrenner, U. (1979). The ecology of human development. Cambridge, MA: Harvard University Press.

Byng-Hall, J. (1985). The family script: A useful bridge between theory and practice, Journal of Family Therapy, 7, 301-305.

Cain, A. C., \& Fast, I. (1972). Children's disturbed reactions to parent suicide. In A. C. Cain (Ed,), Survivors of suicide (pp. 93-111). Springfield, IL: Charles C Thomas.

Cassidy, J. (1988), The self as related to child-mother attachment at six. Child Development, 59, 121-134.

Chodorow, N. (1978). The reproduction of mothering: Psychoanalysis and the sociology of gender. Berkeley, CA: University of California Press.

Cicchetti, D., \& Barnett, D. (1991). Attachment organization in maltreated preschoolers. Development and Psychopathology, 3, 397-411.

Cicirelli, V. G. (1989). Feelings of attachment to siblings and well-being in later life. Psychology and Aging, 4, 211-216.

Cicirelli, V. G. (1991). Attachment theory in old age: Protection of the attached figure. In K. Pillemer \& K. McCartney (Eds.), Parent-child relations across the life course (pp. 25-42). Hillsdale, NJ: Erlbaum.

Craik, K. (1943). The nature of explanation. Cambridge, England: Cambridge University Press.

Crittenden, P. M. (1983). The effect of mandatory protective daycare on mutual attachment in maltreating mother-infant dyads. Child Abuse and Neglect, 7, 297-300.

Dixon, N. F. (1971). Subliminal perception: The nature of a controversy. London: McGraw-Hill.

Dunn, J. (1988). The beginnings of social understanding. Cambridge, MA: Harvard University Press,

Erdelyi, H. M. (1974). A new look at the new look: Perceptual defense and vigilance. Psychological Review, 81, 1-25.

Erikson, F. (1950). Childhood and society. New York: Norton.

Fairbairn, W. R. D. (1952). An object-relations theory of the personality. New York: Basic 
Books.

Firth, R. (1936). We, the Tikopia. London: Allen \& Unwin.

Fish, M., Belsky, 3., \& Youngblade, L. (1991), Developmental antecedents and measurement of intergenerational boundary violation in a nonclinic sample. Family Psychology, 4, 278-297.

Fonagy, P., Steele, M., \& Steele, H. (1991). Intergenerational patterns of attachment: Maternal representations during pregnancy and subsequent infant- mother attachments. Child Development, 62, 891-905.

Foss, B. M. (1961). Determinants of infant behaviour (Vol. 1). London: Methuen.

Foss, B. M. (1963). Determinants of infant behavior (Vol. 2). London: Methuen.

Foss, B. M. (1965). Determinants of infant behaviour (Vol. 3). London: Merhuen.

Foss, B. M. (1969). Determinants of infant behaviour(Vol. 4). London: Methuen.

Freud, A. (1960), Discussion of Dr, John Bowlby's paper. Psychoanalytic Study of the Child, 15, 53-62.

Freud, S. (1953). Three essays on the theory of sexuality. In J. Strachey (Ed. and Trans.), The standard edition of the complete psychological works of Sigmund Freud (Vol. 7, pp. 125-245). London: Hogarth Press. (Original work published 1905)

Freud, S. (1955). The psychogenesis of a case of homosexuality in a woman. In 3. Strachey (Ed. and Trans.), The standard edition of the complete psychological works of Sigmund Freud (Vol. 18, pp. 145-172). London: Hogarth Press. (Original work published 1920)

Freud, S. (1959). Inhibitions, symptoms and anxiety. In 3. Strachey (Ed. and Trans.), The standard edition of the complete psychological works of Sigmund Freud (Vol. 20, pp. 77-175). London: Hogarth Press. (Original work published 1926).

Freud, S. (1961). The ego and the id, In 3. Strachey (Ed. and Trans.), The standard edition of the complete psychological works of Sigmund Freud (Vol. 19, pp. 3- 66). London: Hogarth Press. (Original work published 1923).

Freud, S. (1964). An outline of psycho-analysis. In J. Strachey (Ed. and Trans.), The standard edition of the complete psychological works of Sigmund Freud (Vol. 23, pp. 141-207). London: Hogarth Press. (Original work published 1940).

George, C., Kaplan, N., \& Main, M. (1984). Adult attachment interview. Unpublished manuscript, University of California, Berkeley.

George, C., \& Solomon, J. (1989), Internal working models of parenting and security of attachment at age six, Infant Mental Health Journal, 10, 222-237.

Goldfarb, W. (1943). The effects of early institutional care on adolescent personality. Journal of Experimental Education, 14, 441-447.

Goldfarb, W. (1945). Psychological privation in infancy and subsequent adjustment. American Journal of Orthopsychiatry, 15, 247-255.

Greenberg, M. T., \& Marvin, R. 5. (1979). Attachment patterns in profoundly deaf preschool children. Merrill-Palmer Quarterly, 25, 265-279. 
Greenberg, M. T., \& Speltz, M. L. (1988). Attachment and the ontogeny of conduct problems. In 3. Belsky \& T. Nezworski (Eds.), Clinical implications of attachment (pp. 177-218). Hillsdale, NJ: Erlhaum.

Grosskurth, P. (1987). Melanie Klein: Her world and her work, Cambridge, MA: Harvard University Press.

Grossmann, K., Grossmann, K. E., Spangler, G., Suess, G., \& Unzner, L. (1985). Maternal sensitivity and newborns' orientation responses as related to quality of attachment in Northern Germany. In I. Bretherton \& E. Waters (Eds.), Growing points of attachment theory and research, Monographs of the Society for Research in Child Development, 50 (1-2, Serial No. 209).

Grossmann, K. F., \& Grossmann, K. (1990). The wider concept of attachment in cross-cultural research. Human Development, 13, 31 -47.

Hansburg, H. G. (197\%). Adolescent separation anxiety: A method for the study of adolescent separation problems. Springfield, IL: Charles C Thomas.

Harlow, H. F. (1961). The development of affectional patterns in infant monkeys. In B. M. Foss (Ed,), Determinants of infant behaviour (pp. 75-97). London: Methuen.

Harlow, H. F., \& Zimmermann, R. R. (1958). The development of affective responsiveness in infant monkeys. Proceedings of the American Philosophical Society, 102, 501 -509.

Heinicke, C. M. (1956). Some effects of separating two-year-olds from their parents: A comparative study. Human Relations, 9, 105-176.

Heinicke, C. M., \& Westheimer, I. (1966). Brief separations. New York: International Universities Press.

Hermans, H. J. M., Kempen, H. 3. 0., \& van Loon, R. J. P. (1992). The dialogic self. American Psychologist, 47, 23- 33.

Hinde, R. A. (1991). Relationships, attachment, and culture: A tribute to John Bowlby. Infant Mental Health Journal, 12, 154-163.

Hinde, R. A., \& Spencer-Booth, Y. (1967). The effect of social companions on mother- infant relations in rhesus monkeys. In D. Morris (Ed.), Primate ethology (pp. 267-286), London: Weidenfeld and Nicolson.

Howes, C., Rodning, C., Galuzzo, D. C., \& Myers, 1. (1988). Attachment and child care: Relationships with mother and caregiver. Early Childhood Research Quarterly, 3, 403-416.

Johnson, M. M. (1988). Strong mothers, weak wives. Berkeley, CA: University of California Press.

Kaplan, N. (1984). Internal representations of separation experiences in six-year-olds: Related to actual experiences of separation. Unpublished master's thesis, University of California, Berkeley.

Klagsbrun, M., \& Bowlby, J. (1976). Responses to separation from parents: A clinical test for young children. British Journal of Projective Psychology, 21 7-21. 
Klein, M. (1932). The psycho-analysis of children. London: Hogarth Press.

Klopfer, B., Ainsworth, M. D., Klopfer, W. F., \& Holt, R. B., (1954). Developments in the Rorschach technique (Vol. 1). Yonkers-on-Hudson, NY: World Book.

Kobak, B.. R., \& Sceery, A. (1988). Attachment in late adolescence: Working models, affect regulation, and perceptions of self and others. Child Development, 59, 135-146.

Kotelchuck, M. (1972). The nature of the child's tie to his father. Unpublished doctoral dissertation, Harvard University.

Kubler-Ross, E. (1970). On death and dying. London: Tavistock.

Lamb, M. E. (1978). Qualitative aspects of mother-infant and father-infant attachments in the second year of life. Infant Behavior and Development, 1, 265-275.

Lieberman, A. (1977). Preschoolers' competence with a peer: Relations with attachment and peer experience. Child Development, 48, 1277-1287.

Lieberman, A. F., \& Pawl, 3. H. (1988). Clinical applications of attachment theory. In J. Belsky \& T. Nezworski (Eds.), Clinical applications of attachment (pp. 327-351). Hilldale, NJ: Erlbaum.

Lorenz, K. Z. (1935). Der Kumpan in der Umwelt des Vogels (The companion in the bird's world). Journal fur Ornithologie, 83, 137-213. (Abbreviated English translation published 1937 in $A u k, 54,245-273$.

Main, M. (1973). Exploration, play, and cognitive functioning as related to child-mother attachment. Unpublished doctoral dissertation, Johns Hopkins University, Baltimore.

Main, M., \& Goldwyn, B.. (in press). Interview-based adult attachment classifications: Related to infant-mother and infant-father attachment. Developmental Psychology.

Main, M., Kaplan, K., \& (Cassidy, J. (1985). Security in infancy, childhood and adulthood: A move to the level of representation. In I. Bretherton \& E. Waters (Eds.), Growing points of attachment theory and research, Monographs of the Society for Research in Child Development, 50(1-2, Serial No. 209), 66- 104.

Marris, P. (1958). Widows and their families. London: Routledge.

Morris, P. (1982). Attachment and society. In C. M. Parkes \& J. Stevenson-Hinde (Eds.), The place of attachment in human behavior (pp. 185-201). New York: Basic Books.

Marris, P. (1991). The social construction of uncertainty. In C. M, Parkes, J. Stevenson-Hinde, \& P. Morris (Eds.), Attachment across the life cycle (pp. 77- 90). London: Routledge.

Marvin, B.. 5. (1972). Attachment and cooperative behavior in 2-, 3-, and 4 year-olds. Unpublished doctoral dissertation, University of Chicago.

Marvin, R. S. (1977). An ethological-cognitive model for the attenuation of mother-child attachment behavior. In T. M. Alloway, L. Krames, \& P. Pliner (Eds.), Advances in the study of communication and affect, Vol. 3: The development of social attachments (pp. 25-60). New York: Plenum Press,

Marvin, B.. S., \& Stewart, B.. B. (1990). A family system framework for the study of attachment. 
In M. Greenberg, D. Cicchetti, \& M. Cummings (Eds.), Attachment beyond the preschool years (pp. 51 -86), Chicago: University of Chicago Press.

Mains, L., Arend, B.. A., \& Sroufe, L. A. (1978). Continuity and adaptation in the second year: The relationship between quality of attachment and later competence. Child Development, 49, 547-556.

Miller, G. A., Galanter, F., \& Pribram, K. H. (1960). Plans and the structure of behavior. New York: Holt, Rinehart \& Winston.

Miyake, K, Chen, S., \& Campos, 3. (1985). Infants' temperament, mothers' mode of interaction and attachment in Japan: An interim report. hi I. Bretherton \& F. Waters (Eds.), Growing points of attachment theory and research, Monographs of the Society for Research in Child Development, 50(1-2, Serial No. 109), 276-297.

Parke, R. D., \& Tinsley, B. J. (1987). Family interaction in infancy. In J. D. Osofsky (Ed.), Handbook of infant development (pp. 579-641). New York: Wiley.

Parkes, C. M. (1972). Bereavement: Studies of grief in adult life. New York: International Universities Press.

Piaget, J. (1951). The origin of intelligence in children. New York: International Universities Press.

Piaget, J. (1954). The construction of reality in the child. New York: Basic Books.

Radke-Yarrow, M., Cummings, E. M., Kuczinsky, L., \& Chapman, M. (1985). Patterns of attachment in two- and three-year-olds in normal families and families with parental depression. Child Development, 56, 884-893.

Rayner, E. (1991, November). John Bowlby's contribution, a brief summary. Paper presented at the meeting of the British Psychoanalytic Society held in honor of John Bowlby, London, England.

Robertson, J. (1953a). A two-year-old goes to hospital (Film). Tavistock Child Development Research Unit, London (available through the Penn State Audiovisual Services, University Park, PA).

Robertson, J. (1953b). Some responses of young children to loss of maternal care. Nursing Care, 49, 382- 386.

Robertson, J. \& Bowlby, J. (1952), Responses of young children to separation from their mothers. Courrier of the International Children's Centre, Paris, II, 131-140.

Sagi, A., Aviezer, O., Mayseless, O., Donnell, F., \& Joels, T. (1991, April). Infant-mother attachment in traditional and nontraditional kibbutzim, Paper presented at the biennial meetings of the Society for Research in Child Development, Seattle, WA.

Sagi, A., Lamb, M. F., Lewkowicz, K. S., Shoham, R., Dvir, R., \& Fates, D. (1985). Security of infant-mother, -father, and -metapelet among kibbutz reared Israeli children. In I. Bretherton \& E. Waters (Eds.), Growing points of attachment theory and research, Monographs of the Society for Research in Child Development, 50(1-2, Serial No. 209), 257-275.

Salter, M. D. (1940). An evaluation of adjustment based upon the concept of security. Child 
Development Series. Toronto, Ontario, Canada: University of Toronto Press.

Schaffer, H, R., \& Emerson, P. F. (1964). The development of social attachments in infancy. Monographs of the Society for Research in Child Development, 29 (Serial No. 94).

Schneider-Rosen, K., Braunwald, K. G., Carlson, V., \& Cicchetti, U). (1985). Current perspectives in attachment theory: Illustration from the study of maltreated infants. In 1. Bretherton \& B. Waters (Eds.), Growing points of attachment theory and research, Monographs of the Society for Research in Child Development, 50 (1-2, Serial No. 209), 194-210.

Schur, M. (1960). Discussion of Dr. John Bowlby's paper. Psychoanalytic Study of the Child, 15, 63-84.

Senn, M. J. E. (1977a). Interview with James Robertson. Unpublished manuscript, National Library of Medicine, Washington DC.

Senn, M. J. E. (1977b). Interview with John Bowlby. Unpublished manuscript, National Library of Medicine, Washington, DC.

Shaver, P. R., \& Hazan, C. (1988). A biased overview of the study of love. Journal of Social and Personality Relationships, 5, 473-501.

Slough, N., \& Greenberg, M. (1991). Five-year-olds' representations of separation from parents: Responses for self and a hypothetical child. In W. Damon (Series Ed.) \& I. Bretherton \& M. Watson (Vol. Eds.), Children's perspectives on the family (pp. 67- 84). San Francisco: Jossey-Bass.

Spieker, S., \& Booth, C. (1988). Maternal antecedents of attachment quality. In J. Belsky \& T. Nezworski (Eds.), Clinical implications of attachment (pp. 95-135). Hillsdale, NJ: Erlbaum.

Spitz, R. A. (1946). Anaclitic depression. Psychoanalytic Study of the Child, 2, 313-342.

Spitz, R. A. (1947). Grief: A peril in infancy. Spitz, R. A. (1947). Grief: A peril in infancy (Film). University of Akron Psychology Archives, Akron, Ohio. (available through the Penn State Audiovisual Services, University Park, PA).

Spitz, R. A. (1960). Discussion of Dr. John Bowlby's paper. Psychoanalytic Study of the Child, $15,85-208$.

Sroufe, L. A. (1983). Infant-caregiver attachment and patterns of adaptation in preschool: The roots of maladaptation and competence. In M. Perlmutter (Ed.), Minnesota symposia on child psychology (Vol. 16, pp. 41-81). Hillsdale, NJ: Erlbaum.

Sroufe, L. A. (1985). Attachment classification from the perspective of infant- caregiver relationships and infant temperament. Child Development, 56, 1-14.

Sroufe, L. A. (1988). The role of infant-caregiver attachment in adult development. In J. Belsky \& T. Nezworski (1988), Clinical implications of attachment (pp. 18-38). Hillsdale. NJ; Erlbaum.

Sroufe, L. A., \& Waters, B. (1977). Attachment as an organizational construct. Child Development, 49, 1184-1199.

Stayton, D., \& Ainsworth, M. D. S. (1973). Development of separation behavior in the first year of life. Developmental Psychology, 9, 226- 235. 
Stayton, D., Hogan, R., \& Ainsworth, M. D. S. (1973). Infant obedience and maternal behavior; The origins of socialization reconsidered. Child Development, 42, 1057-1070.

Stewart, R. B., \& Marvin, R. S. (1984). Sibling relations: The role of conceptual perspectivetaking in the ontogeny of sibling caregiving. Child Development, 55, 1322-1332,

Sullivan, H. S. (1953). The interpersonal theory of psychiatry. New York: Norton.

Teti, D. M., \& Ablard, K. B. (1989), Security of attachment and infant-sibling relationships: A laboratory study. Child Development, 60, 1519-1528.

Tinbergen, N. (1951). The study of instinct. London: Clarendon Press.

Tracy, R. L., \& Ainsworth, M. D. S. (1981), Maternal affectionate behavior and infant-mother attachment patterns. Child Development, 52, 1341-1343.

Tracy, R. L., Lamb, M. E., \& Ainsworth, M. D. S. (1976). Infant approach behavior as related to attachment. Child Development, 47, 511- 578.

Tronick, E. Z,, Winn, S., \& Morelli, G, A. (1985). Multiple caretaking in the context of human evolution: Why don't the Efe know the Western prescription to child care? In M. Reite \& T. Field (Eds.), The psychobiology of attachment and separation (pp. 293-321). San Diego: Academic Press.

Tulving, E. (1972). Episodic and semantic memory. In E. Tulving \& W. Donaldson (Eds.), Organization of memory (pp. 382-403). San Diego; Academic Press.

Van Ijzendoorn, M. H., \& Kroonenherg, P. M. (1988). Cross-cultural patterns of attachment; A meta-analysis of the Strange Situation. Child Development, 59, 147-156.

Waddington, C. H. (1957). The strategy of the genes. London: Allen \& Unwin.

Ward, M. J., Carlson, B. A., Altman, S., Levine, L., Greenberg, R. H., \& Kessler, U, B. (1990, April). Predicting infant-mother attachment from adolescents' prenatal working models of relationships. Paper presented at the Seventh International Conference on Infant Studies, Montreal, Quebec, Canada.

Waters, E. (1978). The reliability and stability of individual differences in Infant- mother attachment. Child Development, 49, 520-616.

Waters, E., \& Deane, K. (1985). Defining and assessing individual differences in attachment relationships: Q-methodology and the organization of behavior in infancy and early childhood. in I. Bretherton \& E. Waters (Eds.), Growing points of attachment theory and research, Monographs of the Society for Research in Child Development, 50(1-2, Serial No. 209), 41-65.

Weiss, R. S. (1973). Loneliness: The experience of emotional and social isolation. Cambridge, MA: MIT Press.

Weiss, R. S. (1977). Marital separation. New York: Basic Books.

Weiss, R. S. (1982). Attachment in adult life. In C. M. Parkes \& J. Stevenson-Hinde (Eds.), The place of attachment in human behavior (pp. 111-184). New York: Wiley. 
Weiss, R. (1991). The attachment bond in childhood and adulthood. In C. M. Parkes, J. Stevenson-Hinde, \& P. Marris (Eds.), Attachment across the life cycle (pp. 66-76), London: Routledge.

Winnicott, D. W. (1965). The maturational process and the facilitating environment. New York: International Universities Press.

Young, J. Z. (1964). A model for the brain. London: Oxford University Press. 